\title{
Investigation of the views of teachers toward the use of smart boards in the teaching and learning process
}

\author{
Furkan Bıçak \\ Trabzon University, Institute of Educational Sciences, Turkey
}

\begin{tabular}{|c|c|}
\hline Article Info & Abstract \\
\hline $\begin{array}{l}\text { Article History } \\
\text { Submitted: 16 July } 2018 \\
\text { Revised: } 23 \text { November } 2018 \\
\text { Published online: } 1 \text { April } 2019\end{array}$ & $\begin{array}{l}\text { This study was carried out to determine the teachers' views on the usability of } \\
\text { the smart board in the classroom and their needs to adapt it in the teaching } \\
\text { process. Case study method was adopted in the study. The study was } \\
\text { conducted on } 10 \text { different middle school branch teachers who were working at } \\
\text { public schools in a northern province of Turkey. As data collection tool, a semi- } \\
\text { structured interview form which is used commonly in qualitative research }\end{array}$ \\
\hline $\begin{array}{l}\text { Keywords } \\
\text { Smart board } \\
\text { Teacher views } \\
\text { Technology }\end{array}$ & $\begin{array}{l}\text { methods was established. The data obtained were evaluated within the context } \\
\text { of content and descriptive analysis techniques. The results revealed that } \\
\text { although teachers expressed a positive opinion on smart board practices, they } \\
\text { stated that they were insufficient in the use of smart boards and that they } \\
\text { needed more practice-oriented in-service courses. Depending on the results, } \\
\text { some suggestions have been made about smart board applications and } \\
\text { seminars to be given to teachers. }\end{array}$ \\
\hline
\end{tabular}

\section{Introduction}

The age of information and technology that we are in has a positive impact on the development of societies by influencing societies in every aspect of production and consumption in the globalized world. Emerging societies are based on knowledge and technology and their level of development is determined by these two components. In the light of the scientific developments in recent years, reform movements in education and instructional technologies have become a part of the modern education. The tools and materials used in education are very critical in order to meet the needs of the day by renewing them, providing them with current approaches and technological developments (Powers \& Blubaugh, 2005).

In line with the needs of societies, educational technologies are progressing and therefore, it is provided for educational institutions to educate qualified individuals and to find solutions to the faced problems during training process (Kirschner \& Selinger, 2003). From the simplest structured technologies to the most complex technological systems, many technologies have been used for different purposes in our teaching environments. Over time, in parallel with the development of science and technology, overhead projector, episcopes, computers, projection devices and smart technology with the latest technological equipment have been introduced in educational environments such as smart board, aims to make the learning process more effective (Becta, 2006).

Address of Corresponding Author

Furkan Bıçak, Trabzon University, Institute of Educational Sciences, Fatih Faculty of Education Campus, 61300, Sogutlu, Akcaabat, Trabzon / Turkey

\section{$\triangle$ furkan_bicak@hotmail.com}

0000-0002-2137-0161

How to cite: Biçak, F. (2019). Investigation of the views of teachers toward the use of smart boards in the teaching and learning process. Journal of Pedagogical Research, 3(1), 15-23. doi: 10.33902/JPR.2019.1 
The budget allocated to educational technology in Turkey is lower than in developed countries. However, this rate is above many developing countries. On the other hand, although significant increases were observed in Internet and computer use within the framework of the investments made in our country, the ratio in developed countries still could not be achieved (Tezci, 2009). Compared to other countries in recent years, Turkey has showed a marked improvement with investments regarding technological developments such as using technology and smart boards in the classrooms (Baran, 2010). Although smart boards are high-tech equipment, they increase the quality of education and support teaching and learning in all subjects in the classroom (Kennewell \& Beauchamp, 2007; Smith, Higgins, Wall, \& Miller, 2005).

When the previous studies at national and international level are examined, it is found that the materials used in courses concretize the subjects and provide a better understanding of the content to students, and the students show more interest to the lesson (Bastug \& Kircaburun, 2017; Cabus, Haelermans, \& Franken, 2017; Demirci, Taş \& Özel, 2007). From the perspective of Turkey, although some of the public schools have technological infrastructure problems, these problems are trying to be minimized quickly. For instance, in the context of FATIH (Movement of Enhancing Opportunities and Improving Technology) Project, 7 billion USD has been allocated for technology use in classrooms, and smart boards and tablet computers have been delivered to 600,000 classrooms and 40,000 public schools throughout Turkey. Thus, it is aimed to reduce inequality in education system, to achieve success in quality and quantity and to equip students with problem solving skills as one of the components of educational targets (Gökçe, Aydoğan-Yenmez, \& Özpınar, 2016; Sarıtepeci, Durak, \& Seferoğlu, 2016).

The studies carried out in recent years support the idea that smart boards increase the concentration and attention of students during class time due to their visual characteristics, increase their motivation for courses and contribute to the improvement of their learning and increase their academic achievement (Baran, 2010; Lai, 2010; Marzano, 2009; Slay, Siebörger, \& Hodgkinson-Williams, 2008). Rüzgar's (2005) experimental study on students revealed that the technology used in the experimental group provided the acquisition of knowledge and improved student achievement more compared to the traditional classroom environments. According to Alkan (1998), when educational environments are used appropriately in learning processes, a variety of benefits can be observed. For instance, learning becomes easier and active, perceptions are strengthened, interest towards learning and persistence of acquired impressions increase, and learning is enriched. Therefore, the use of more advanced teaching tools in terms of quality and quantity as a result of such developments in educational technologies provides many benefits, including improving the quality of education and reaching the general and specific objectives of education (Kazu \& Yeşilyurt, 2008).

Nowadays, when the applications of technology of many countries are examined, it is seen that computers, LCD projectors and Internet are the main technologies in classrooms as a part of modern teaching techniques. Considering that the FATIH project, which is being implemented in Turkey, takes the use of technology products in education-training activities to the core, it can be said that this study is important in terms of investigating opinions of teachers about the use of smart boards.

In the literature, many studies have shown that smart board increases meaningful learning (Lipton \& Lipton, 2010), contributes positively to the students' academic achievements (Akçayır, 2011; Akdemir, 2009; Ekici, 2008), increases student motivation (Akçayır, 2011; Akdemir, 2009; Altınçelik, 2009) and affects their attitudes positively (Tataroğlu, 2009; Akçayır, 2011). Smart boards, on the other hand, are technological tools and require very complex and technical skills to use. In order to use these tools more effectively, both software and hardware need to be adequately structured. The present study aimed at investigating teachers' views on the use of smart board and revealing teachers' needs. 


\section{Method}

\subsection{Research Design}

In this study, case study approach was used as a component of descriptive research methods. Due to the nature of case studies in the research process, individuals or processes are investigated through a holistic approach. This case study was adopted in this study since special cases were to be investigated in an in-depth way (Çepni, 2009).

\subsection{Participants}

The study group consists of 10 teachers from different branches. The participants are working in an area located north of Turkey. Table 1 shows the demographic data of the participants of the study and the level of self-declared computer use.

Table 1.

Preliminary information about the teachers involved in the research

\begin{tabular}{cccc}
\hline Teacher Code & Gender & Age & Computer Usage Level \\
\hline T1 & Female & 24 & Medium \\
\hline T2 & Female & 26 & Strong \\
\hline T3 & Male & 35 & Strong \\
\hline T4 & Male & 28 & Very strong \\
T5 & Male & 36 & Medium \\
\hline T6 & Female & 30 & Medium \\
\hline T7 & Male & 42 & Medium \\
\hline T8 & Male & 33 & Strong \\
\hline T9 & Female & 32 & Very strong \\
\hline T10 & Female & 41 & Medium
\end{tabular}

When Table 1 is examined, it is seen that the distribution of teachers by gender is balanced. Considering the age of the teachers, it can be said that there is a young participant population. Finally, it can be said that the computer use of teachers is medium and above.

\subsection{Data Collection Tool}

The data of this qualitative study were collected through semi-structured interviews. Semistructured interviews are more advantageous in terms of making certain situations more descriptive by asking questions in depth on a specific subject, asking questions in different ways again if the given answer is incomplete or unclear (Çepni, 2009). The teachers who participated in this research study were asked six questions in semi-structured interview forms. Interview questions are provided in Appendix 1.

\subsection{Validity and Reliability of the Study}

Validity and reliability expressions are more appropriate for quantitative research. In qualitative research, validity and reliability are replaced by credibility, transferability, consistency, and verifiable statements (Denzin \& Lincoln, 1994). In order to provide these components, first of all, the interview questions were examined by academicians who were experts in their field. In this direction, some additions and subtractions have been made and the comprehensibility of the questions has been tested. Finally, the analysis of the data was done by two researchers and a consensus was sought.

\subsection{Data Analysis}

Descriptive and content analysis were used in the analysis of the interview data. Interview data were recorded with the approval of the participants and then transcribed. The data obtained after all these studies were read over and the data were excluded from the scope of the study for 
reduction. The coding process was started on the reduced data. The expressions created as a result of the inferences made in the codes are turned into themes and transformed into meaningful format for the reader. By creating tables and graphs from the obtained themes, understanding of the reader is facilitated. In order to better understand the tables, the findings in the table were supported by quotations from the interviews. In this way, the results were reported by targeting to obtain meaningful results (Yıldırım \& Şimşek, 2006). In addition, participant teachers were coded as $\mathrm{T} 1, \mathrm{~T} 2, \mathrm{~T} 3, \ldots . . . . \mathrm{T} 10$. The obtained matrices were used to summarize the data.

\section{Results}

In this section, the findings are presented. Each emerging idea is considered according to the problem statement and the matrices and descriptions reflecting these opinions and thoughts are presented. Table 2 provides a summary of the opinions of the participant teachers on the use of smart boards in the education process.

As a general evaluation, it is seen that all of the teachers stated that technology is a sine qua non for the education field. In addition, all teachers think that smart boards will attract students' attention thanks to the visuals. Teachers also think that the blackboard, which is an important part of the traditional classroom environment, will be replaced by the smart board in the future. Some of the most frequent answers are that teachers find the smart board seminars given to them very theoretical. Teachers who felt support at this point stated that they should be given more help through seminars in areas where they are inadequate. In addition, teachers want the seminars to be practice-oriented. In the following section, the results will be presented in detailed. More specifically, the themes are outlined in Figure 1 to illustrate the reason why teachers need smart boards.

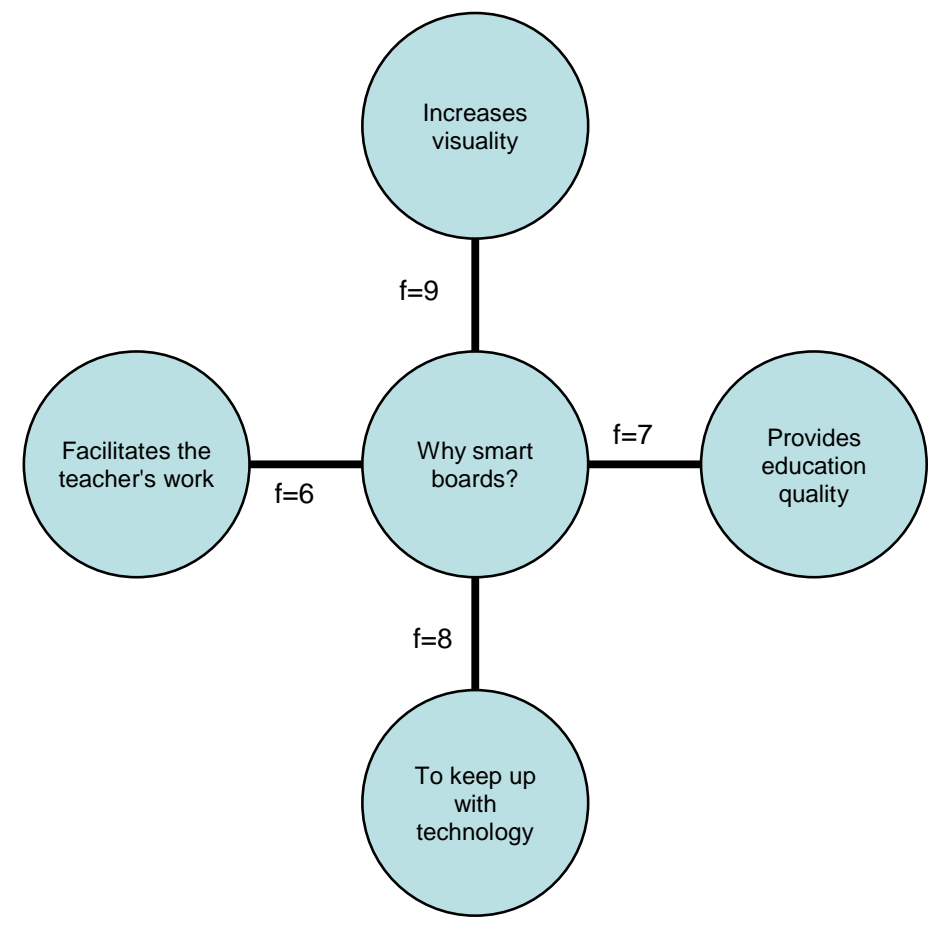

Figure 1. Teachers' views on why they need a smart board

When Figure 1 is examined, it is seen that most of the teachers stated that they need a smart board to keep up with the technology. On the other hand, almost all teachers stated that smart boards increased the visualization, and therefore, a useful material. Seven teachers stated that the smart board would improve the quality of education and six teachers would reduce their workload. In this respect, it is seen that some of the answers given by the teachers are prominent 
and some of them have brought the students to the forefront. A teacher response related to the two codes of the theme is as follows:

T4: "There is a need for a smart board. Because to keep pace with technology, there should be innovations in education and I think that smart boards will increase the quality of education."

In another theme, there are codes obtained from teachers' views on the advantages and disadvantages of smart boards in the context of classroom management (CM). The relevant data are presented in Table 2.

Table 2.

Teachers' views on the pros and cons of smart board in the context of CM

\begin{tabular}{|c|c|c|}
\hline & Codes & $\mathbf{f}$ \\
\hline \multirow{6}{*}{$\begin{array}{l}\text { Positive } \\
\text { thoughts }\end{array}$} & Can be used in all courses. & 10 \\
\hline & Teachers end up dealing with a blackboard. & 10 \\
\hline & Figures and animations attract students & 10 \\
\hline & Reduces teacher workload. & 8 \\
\hline & The teacher saves time. & 8 \\
\hline & It facilitates class control. & 6 \\
\hline \multirow{4}{*}{$\begin{array}{l}\text { Negative } \\
\text { thoughts }\end{array}$} & Discipline problems & 3 \\
\hline & Increases workload. & 1 \\
\hline & Waste of time sometimes. & 1 \\
\hline & Nothing changes & 1 \\
\hline
\end{tabular}

When Table 2 is examined, it can be seen that all the teachers think that smart boards can be used in all courses. In addition, it can be said that all teachers think that smart boards will replace blackboards soon. Teachers' responses on the idea that the smart board will provide to facilitate classroom management and save time are also other positive opinions. Although the negative opinions of the teachers are very few, the striking point among them is that smart board is seen as discipline problems, loss of time, increase the workload and do not provide any change. One of the sample responses about the positive thoughts of the teachers is as follow:

T7: "The smart board can of course be easily used in all courses. In my own lesson, I can present the cell membrane of students to the cell membrane, for example, the organelles can be connected to the Internet in a picture and shape. In this way, I use visuals and save time."

In a different question, the teachers were asked to evaluate the seminars given for the use of smart boards. The relevant codes are given in Table 3.

Table 3.

Teachers' evaluations on blackboard education seminars

\begin{tabular}{lc}
\hline Codes & $\mathbf{f}$ \\
\hline In the seminars, the trainings given to the teachers about the smart board are insufficient. & 10 \\
\hline The seminar is theoretical. & 10 \\
\hline Teachers should be adapted to the smart board by giving more practice with more seminars. & 10 \\
\hline The timing was incorrect when planning seminars. & 6 \\
\hline Teachers are inadequate in using technology. & 4 \\
\hline
\end{tabular}

One of the biggest criticisms of the teachers towards seminars is that the number of these seminars is insufficient and the seminars are more theoretical. Indeed, one of the most repetitive codes is that teachers state that they need practical based seminars. Some teachers have stated that their colleagues are insufficient in technology. Some of the teachers think that seminars are being organized at inappropriate times. Two of the critics are given below: 
T10: "At the seminar, there was a smart board in the hall; we saw it and we had the opportunity to touch it at the end of the seminar for a couple minute. We did not receive application-level training. We were just shown it theoretically. At the seminar, there was no opportunity to discover the features of practice by way of trial and error. The seminar was on weekdays therefore the timing was incorrect. It would have been more effective if it had been done in a more productive time and practically given to the teachers."

T6: "The beginning teachers are experts on these issues (means technology). But older teachers in the profession are quite foreign to the technology. There are teachers who are not yet able to fully use the computer and these teachers should be given more seminars. I think the new teachers do not have difficulties. However, old friends who are nearing retirement are very difficult to work on smart boards and I think that the differentiation in this regard can be closed by giving them more seminars."

The data obtained from the interview question where teachers stated their opinions about the effect of smart boards on affective factors and academic achievement are summarized in Table 4 .

Table 4.

Effect of smart boards on affective factors and success

\begin{tabular}{lc}
\hline Codes & $\mathbf{f}$ \\
\hline Improves student success. & 10 \\
\hline Increases the student's interest and motivation. & 8 \\
\hline $\begin{array}{l}\text { Smart board enhances success with family-student and teacher } \\
\text { collaboration. }\end{array}$ & 8 \\
\hline Increases the student engagement. & 7 \\
\hline Smart board alone cannot increase success. & 6 \\
\hline The deterioration of the tablets reduces the interest of the students. & 4 \\
\hline
\end{tabular}

According to Table 4, the teachers indicated that smart board has a potential to increase student success, but some teachers stated that the smart boards were not enough to achieve success alone. As an important finding, some teachers believe that smart boards will increase student interest and motivation. In addition, seven teachers believe that this material will increase student participation. A sample teacher response is as follows:

T2: "When the smart board is snagged in the classroom, it will be an unknown material and will take the interest of students. It will arouse the curiosity because they will experience something like this for the first time, so I think it will provide a positive motivation by increasing their interest to the course."

Finally, teachers were asked to state what they think about the relationship between technology and education. Regarding this question, the purpose was to reveal how they look at education through the technological window. The findings are as in Table 5.

Table 5.

Teacher views on the interaction between technology and education

\begin{tabular}{lc}
\hline Codes & f \\
\hline As in every field, technology is needed in education. & 10 \\
\hline Technology has emerged through education. & 6 \\
\hline Education and technology are parallel concepts. & 6 \\
\hline Technology is required for quality training. & 5 \\
\hline Technological innovations affect our education system. & 4 \\
\hline
\end{tabular}


When Table 5 is examined, it is seen that all of the teachers stated that technology is required in education as in every field. Some of the teachers pointed out that education influences the technology, and that the technology has been developing thanks to the education. On the other hand, some of the teachers stated that technology is needed for effective teaching as well as updating the education system. One of the teacher responses is presented above.

T7: Technology makes human life easier in every sense. Smart phones, computers and etc. It provides fast and easy access to information with internet usage. In order to provide better teaching quality, we need to use technological materials that are appropriate to the requirements of the era.

\section{Discussion and Conclusion}

The aim of this study was to determine the opinions of teachers on the use of smart boards in schools and the needs about the usage of the smart boards in the classrooms. Based on the data obtained from the study, it was observed that nearly all of the teachers had positive opinions about smart boards. It is pleasing that teachers have positive perspectives towards technological materials. As a matter of fact, most of the studies carried out emphasize the positive outcomes of integrating smart boards into classroom environments (Kaya, 2013; Kennewel, 2006).

Many studies in the literature have examined the effects of smart boards on affective factors and some of them reported the contribution of smart boards to the students' motivation (e.g. Akbas \& Pektaş, 2011; Kennewell \& Beauchamp, 2007; Torff \& Tirotta, 2010), interest (e.g. Onder \& Aydin, 2016; Sevim \& Sayir, 2017) and their engagement (Jelyani, Janfaza, \& Soori, 2014). The findings of this study revealed that teachers' opinions were in line with these research results. In other words, teachers stated that the use of smart boards in classrooms would increase the motivation of students and increase their involvement and participation. Another result of the study is that teachers need support for the use of smart boards. Almost all of the participants showed that the in-service courses or seminars related to the smart board were theoretical although a practical content was needed, the time allocated for the seminar was low and that the seminar schedule was not selected appropriately. Some study results in the literature also indicate that the courses given to teachers are more in theoretical content and therefore do not attract teachers' attention (Keleş \& Çelik, 2013). Similar conclusions can be found in the results of this study. On the other hand, some teachers' comments about their colleagues show that the level of technology use for elder teachers is low. In this context, in-service courses should also be designed for teachers who have not received technology-supported teaching courses in undergraduate education. Indeed, some studies have shown that older teachers are resistant to technology (Özgür, 2013).

The effects of the use of materials in classroom environment on teachers' classroom management were examined by many researchers. Şahin (2015) collected data from 512 teachers, and according to the results, teachers have partially agreed that the use of materials in classrooms will help preventing the disciplinary problems and help facilitating classroom management. Similarly, in this study, teachers think that the use of smart boards in classrooms will facilitate classroom management. Finally, teachers' opinions on the relationship between education and technology have also provided some evidences about teachers' view on smart boards. First of all, teachers' positive outlook on the use of technology in the educational environment can be interpreted as an indicator of their positive attitude and belief towards smart boards. Considering the effect of teachers' beliefs on their teaching (Çelik et al., 2018), it can be said that the results will have positive effects on teaching activities.

\section{Suggestions}

Based on the results and the implementation process, the following suggestions are presented:

- Smart board seminars need to be increased. In this respect, it is considered that seminars or in-service courses that may give more practical opportunities to teachers are required.

- Not only smart boards, but teachers need support courses to deepen their technological infrastructure. 
- In this study, teachers' opinions were examined. Studies that reveal reflections from the real classroom environment are needed.

- This study is a qualitative research. It can be ensured that the views of larger participants can be obtained through quantitative research and surveys.

\section{References}

Baran, B. (2010). Experiences from the process of designing lessons with interactive whiteboard: Assure as a road map. Contemporary Educational Technology, 1 (4), 367-380.

BECTA (2006). Teaching interactively with electronic whiteboards in the primary phase. Retrieved from http://www.edubcn.cat/rcs_gene/9_teaching_interactively_whiteboards.pdf [08.01.2016]

Cabus, S. J., Haelermans, C., \& Franken, S. (2017). SMART in Mathematics? Exploring the effects of in class level differentiation using SMART board on math proficiency. British Journal of Educational Technology, 48(1), 145-161.

Çelik, D., Özmen, Z. M., Aydın, S., Güler, M., Birgin, O., Açıkyıldız, G., ... \& Gürbüz, R. (2018). A national comparison of pre-service elementary mathematics teachers' beliefs about mathematics: The case of Turkey. Education \& Science/Egitim ve Bilim, 42(193), 289-315.

Çepni, S. (2009). Araştırma ve proje çalı̧malarına giriş [Introduction to research and project studies] (4th edition). Trabzon: Celepler Matbaacillk

Demirci, A., Taş, H. İ., \& Özel, A. (2007). The use of technology at secondary school geography lessons in Turkey. Marmara Geographical Review, 15(2), 37-54.

Denzin, N. K. \& Lincoln, Y. S. (1994). Handbook of qualitative research. CITY, CA: Sage Publications,

Ekici, F. (2008). Effects of smart board usage on primary school maths students' success. Unpublished master thesis. Marmara University, İstanbul.

Gökçe, S., Yenmez, A. A., \& Özpınar, İ. (2016). Mathematics teachers' opinions on worksheets prepared with geogebra. Turkish Journal of Computer and Mathematics Education, 7(1), 164-187.

Jelyani, S. J., Janfaza, A., \& Soori, A. (2014). Integration of SMART boards in EFL classrooms. International Journal of Education and Literacy Studies, 2(2), 20-23.

Kaya, G. (2013). The effects of using interactive whiteboards on students' achievement of transformational geometry in mathematics lessons. Unpublished Master thesis. Gazi University, Ankara.

Kazu, H. \& Yeşilyurt, E. (2008). Teacher's aims of using instructional tools and materials. Firat University Journal of Social Science, 18(2), 175-188.

Keleş, E., \& Çelik, D. (2000). Investigation of in-service training courses performed about computer technologies and their application in education between 2000 and 2010 in Turkey. Journal of Instructional Technologies \& Teacher Education, 2(1), 164-194.

Kennewel, S. (2006, October). Reflections on the interactive whiteboard phenomenon: a synthesis of research from the U.K. Paperpresented at The AARE Conference, Adelaide, Australia.

Kennewell, S. \& Beauchamp, G. (2007). The features of interactive whiteboards and their influence on learning. Learning, Media and Technology, 32(3), 227-241.

Lai, H. J. (2010). Secondary school teachers' perceptions of interactive whiteboard training workshops: A case study from Taiwan. Educational Technology, 26(4), 511-522.

Lipton, M. L., \& Lipton, L. G. (2010) Enhancing the radiology learning experience with electronic white board technology. American Journal of Roentgenology, 194(6), 1547-1551.

Marzano, R .J. (2009). Teaching with interactive whiteboards. Educational Leadership, 67(3), 80-82.

Onder, R., \& Aydin, H. (2016). Students' views towards the usage of smart board in biology lessons. Journal on School Educational Technology, 11(3), 18-28.

Özgür, H. (2013). Bilişim teknolojileri öğretmen adaylarının eleştirel düşünme eğilimleri ile bireysel yenilikçilik özellikleri arasındaki ilişkinin çeşitli değişkenler açısından incelenmesi [Exploring of the relationship between critical thinking dispositions and individual innovativeness of ICT pre-service teachers in terms of various variables]. Mersin University Journal of the Faculty of Education, 9(2), 409-420.

Powers, R., \& Blubaugh, W. (2005). Technology in mathematics education: Preparing teachers for the future. Contemporary Issues in Technology and Teacher Education, 5(3), 254-270.

Rüzgar, B. (2005). Bilginin eğitim teknolojilerinden yaralanarak eğitimde paylaşımı. The Turkish Online Journal of Educational Technology, 4(3), 1303- 521. 
Sarıtepeci, M., Durak, H., \& Seferoğlu, S. S. (2016). Examination of teachers' in-service training needs in the field of instructional technology: an evaluation in light of applications implemented at FATIH project. Turkish Journal of Computer and Mathematics Education, 7(3), 601-620.

Sevim, O., \& Sayır, F. (2017). Investigating interactive white board speaking skills activities in Turkish lessons according to teachers' and students' ideas. International Journal of Turkish Education Sciences, 5(8), 160-172.

Slay, H., Siebörger, I., \& Hodgkinson-Williams, C. (2008). Interactive whiteboards: Real beauty or just "lipstick? Computers \& Education, 51, 1321-1341.

Smith, H, J., Higgins, S., Wall, K. and Miller, J. (2005). Interactive whiteboards: Boon or bandwagon? A critical review of the literature. Journal of Computer Assisted Learning, 21, 91-101.

Şahin, M . (2016). The analysis of the views of teachers related to the functions of teaching materials during the teaching-learning process. Kastamonu Education Journal, 23(3), 995-1012.

Tataroğlu, B. (2009). The effect of utilizing the smart board in mathematics teaching on 10th grade students, their academic standings, their attitude towards mathematics and their self efficacy levels. Unpublished Master thesis. Dokuz Eylul University, İzmir.

Tezci, E. (2009). Teachers' effect on ICT use in education. The Turkey sample. Procedia Social and Behavioral Sciences, 1, 1285-1294.

Torff, B., \& Tirotta, R. (2010). Interactive whiteboards produce small gains in elementary students' selfreported motivation in mathematics. Computers \& Education, 54(2), 379-383.

Yıldırım, A. \& Şimşek, H. (2005). Sosyal bilimlerde nitel araştırma yöntemleri [Quantitative and qualitative research methods] (5th ed.) Ankara, Turkey: Seçkin Yayınları.

\section{Appendix 1. Interview questions}

1) Do you think there is a need to place smart boards in the classes? Why is that?

2) What do you think is the relationship between technology and teaching and learning? Could you explain it briefly?

3) What are the benefits of smart boards in terms of student interest and motivation?

4) What are the positive or negative aspects of the smart board to improve student achievement?

5) Do you think that the seminars about the usage of smart boards are sufficient? Why is that?

6) What are the pros and cons of the smart board in terms of classroom management? Can you give me an example? 